\title{
Hubungan Tingkat Kecemasan Dengan Hemodinamik Pasien Gagal Ginjal Kronik Yang Menjalani Hemodialisa
}

\section{Correlation Anxiety Level with Hemodynamic of Chronic Renal Failure Patients Under Hemodialysis Treatment}

\author{
Nurlinawati, Dini Rudini, Yuliana \\ Prodi Keperawatan Universitas Jambi \\ HP : 081373564566/E-mail :nurlinawati1983@gmail.com
}

\begin{abstract}
Abstrak : Latar Belakang : Pasien hemodialisis seringkali mengalami kecemasan. Kecemasan ini apabila tidak diatasi akan mempengaruhi aspek fisiologis dan hemodinamik yang dikhawatirkan akan menimbulkan komplikasi yaitu dialysis disequilibrium syndrome. Penelitian ini bertujuan untuk mengetahui hubungan tingkat kecemasan dengan kondisi hemodinamik pasien gagal ginjal kronik yang sedang menjalani hemodialisa.

Metode : Jenis penelitian kuantitatif dengan menggunakan cross sectional. Sampel dalam penelitian ini berjumlah 57 responden. Analisis univariat menggunakan distribusi frekuensi dan analisis bivariat menggunakan regresi linier sederhana.

Hasil : Hasil penelitian didapat tingkat kecemasan hanya berhubungan dengan Mean Arterial Pressure (MAP) sebelum hemodialisis dengan nilai signifikan 0.023 dan sesudah hemodialisis didapatkan nilai signifikan 0.026. Sedangkan nadi dan respirasi rate tidak terdapat hubungan dengan nilai signifikan $>0.05$.

Kesimpulan : Ada hubungan antara tingkat kecemasan dengan Mean Arterial Pressure (MAP) pasien gagal ginjal kronik yang sedang menjalani hemodialisa di ruang Hemodialisa RSUD Raden Mattaher Jambi Tahun 2018.
\end{abstract}

Kata Kunci : Hemodialisa, Hemodinamik, Kecemasan

\section{PENDAHULUAN}

Penyakit kronis menurut World Health Organization (WHO) merupakan penyebab kematian dan masalah kesehatan utama di dunia. Salah satu penyakit kronis tersebut adalah gagal ginjal kronik. Dimana orang mengalami gagal ginjal kronik secara global lebih dari 500 juta orang dan yang harus menjalani hemodialisis sekitar 1,5 juta orang. ${ }^{1}$ Di Indonesia sendiri, orang yang mengalami gagal ginjal kronik dan menjalani terapi hemodialisis telah mengalami peningkatan. Dari data Riset Kesehatan Dasar (Riskesdas) tahun 2013, menunjukkan prevalensi gagal ginjal kronik $0,2 \%$ dari jumlah penduduk Indonesia. ${ }^{2}$

Kemudian Data Indonesian Renal Registry (IRR) tahun 2015, pasien gagal ginjal kronik menjalani dialisis tercatat $30.554 .^{3}$ Di RSUD Raden Mattaher Provinsi Jambi, jumlah pasien gagal ginjal kronik yang menjalani hemodialisa pada tahun 2015 di ruang hemodialisa yaitu berjumlah 107 orang dan pada tahun 2016 meningkat yaitu berjumlah 137 orang. Berdasarkan data yang di peroleh dari rekapitulasi ruang hemodialisa tahun 2015-2016 diketahui jumlah pasien gagal ginjal kronik yang menjalani hemodialisa dari tahun ke tahun terjadi peningkatan. ${ }^{4}$

Pasien gagal ginjal kronik memerlukan suatu penanganan untuk mempertahankan hidupnya, karena gagal ginjal kronik merupakan penyakit dimana terjadinya gangguan pada fungsi ginjal yang mengalami penurunan, dimana tubuh tidak mampu untuk mempertahankan metabolisme dan keseimbangan cairan dan elektrolit. ${ }^{5}$

Metode penunjang yang paling sering untuk penyakit gagal ginjal kronik adalah hemodialisis yang bertujuan menggantikan fungsi ginjal sehingga dapat memperpanjang 
kelangsungan hidup dan proses hemodialisis ini akan berlangsung sepanjang hidup pasien gagal ginjal kronik. ${ }^{6}$

Pasien gagal ginjal kronik yang tidak menjalani hemodialisis maka pasien hanya akan bertahan dalam beberapa hari atau minggu. Oleh karena itu, hidup pasien gagal ginjal kronik bergantung pada hemodialisis. Akan tetapi pasien yang menjalani hemodialisis ini terdapat permasalahan fisiologis dan psikologis. ${ }^{7}$ Permasalahan fisiologis yang sering dialami oleh pasien hemodialisis yaitu jantung berdebar, berkeringat, rasa sesak nafas, gangguan tidur, mudah lelah, sering kencing, sakit kepala, penglihatan kabur, pusing, mual, muntah dan kejang yang merupakan tanda-tanda dari dialysis disequilibrium syndrome. Selain permasalahan fisiologis, orang yang menjalani hemodialisis akan mengalami permasalahan psikologis antara lain kecemasan, depresi, isolasi sosial, kesepian, tidak berdaya dan putus asa. 8

Kecemasan merupakan suatu sinyal yang menyadarkan, memperingatkan adanya bahaya yang mengancam dan memungkinkan seseorang mengambil tindakan untuk mengatasi ancaman. Kecemasan pada hemodialisis ini ditimbulkan karena peralatan dan mesin yang serba asing, selang-selang yang dialiri darah dan ketidaknyamanan berhubungan dengan penusukan alat. ${ }^{9}$ Kecemasan ini apabila tidak diatasi akan mempengaruhi aspek fisiologis pasien hemodialisis dikarenakan tubuh akan merespon hal tersebut seperti peningkatan denyut nadi, sesak nafas, gangguan pencernaan, sulit tidur, mudah lelah, dan lain-lain. ${ }^{10}$ Oleh karena itu, perawat perlu memantau kecemasan dan dampak dari kecemasan tersebut selama dilakukannya hemodialisa.

Dampak fisiologis dari kecemasan terhadap dilakukannya hemodialisa, yang dapat menimbulkan komplikasi adalah meningkatnya denyut jantung, tekanan darah dan frekuensi nafas. Kecemasan apabila dibiarkan akan mempengaruhi kondisi hemodinamik pasiennya. ${ }^{11}$ Hemodinamik yaitu keadaan fungsi kerja seperti fungsi jantung dan paru. Gangguan hemodinamik yang terganggu dapat menimbulkan komplikasi, salah satunya adalah dialysis disequilibrium syndrome yaitu sindromberupa sakit kepala, mual muntah, penglihatan kabur, pusing, jantung berdebar- debar, dan kejang. Oleh karena itu, penting dilakukan pemantauan psikologis untuk mengetahui tingkat kecemasan dan juga penting dilakukan pemantauan fisiologis untuk mengetahui kondisi hemodinamiknya.

Berdasarkan hasil wawancara yang dilakukan peneliti di ruang Hemodialisa RSUD Raden Mattaher Jambi didapatkan bahwa dari 5 orang responden, 4 orang responden mengatakan gelisah, cepat lelah, pusing setelah cuci darah, sakit perut dan juga terjadi peningkatan tekanan darah. Sedangkan 1 orang responden mengatakan baik-baik saja dan hal-hal buruk tidak terjadi dikarenakan pasien sudah terbiasa dengan keadaannya. Meskipun dengan tindakan yang sama, respon yang muncul pada setiap pasien berbeda-beda. Berdasarkan latar belakang masalah tersebut, maka peneliti tertarik untuk melakukan penelitian tentang Hubungan Tingkat Kecemasan dengan Kondisi Hemodinamik Pasien Gagal Ginjal Kronik Yang Menjalani Hemodialisa di Ruang Hemodialisa RSUD Raden Mattaher Jambi.

\section{METODOLOGI PENELITIAN}

Jenis penelitian ini merupakan jenis penelitian kuantitatif dengan menggunakan metode pendekatan cross sectional yaitu suatu penelitian dimana tingkat kecemasan dan kondisi hemodinamik diteliti pada waktu yang sama. ${ }^{12}$ Populasi total pada 
penelitian ini adalah semua pasien gagal ginjal kronik yang menjalani hemodialisa di ruang hemodialisa RSUD Raden Mattaher Provinsi Jambi tahun 2016 yaitu 137 orang. Pengambilan sampel dilakukan dengan metode sampling insidental dengan menggunakan rumus Stanley Lameshow. ${ }^{12}$

Kriteria inklusi dalam penelitian ini yaitu: pasien gagal ginjal kronik yang menjalani hemodialisa dengan rutin yaitu sebanyak 2 kali dalam seminggu, pasien gagal ginjal kronik yang sadar, dapat berkomunikasi dengan baik dan yang bersedia ikut dalam penelitian. Kriteria eksklusi dalam penelitian ini yaitu: pasien gagal ginjal kronik yang tidak bersedia ikut dalam penelitian, pasien gagal ginjal kronik dengan penurunan kesadaran dan pasien gagal ginjal kronik yang mengalami ketidakmampuan berbicara.

Instrumen yang digunakan untuk mengukur tingkat kecemasan dalam penelitian ini adalah kuesioner Zung Self-rating Anxiety Scale (ZSAS). ZSAS merupakan kuesioner baku dalam bahasa inggris yang dirancang oleh William WK Zung. Kemudian kuesioner ini telah dialih bahasakan ke dalam bahasa indonesia. ${ }^{12}$

Kuesioner terdiri dari 20 pernyataan. Interpretasi hasil < 45: dalam rentang normal, 45-59: kecemasan ringan, 60-74: kecemasan sedang, 75 dan lebih kecemasan berat. Untuk mengukur kondisi hemodinamik pada penelitian ini adalah lembar observasi yang terdiri dari mean arterial pressure, nadi dan respirasi rate. Dengan interpretasi hasil untuk mean arterial pressure <70 $\mathrm{mmHg}$ : hipotensi, $70-105 \mathrm{mmHg}$ : normal, dan >105 mmHg: hipertensi.13 Interpretasi hasil untuk nadi <60 x/i: bradikardia, $60-100 \mathrm{x} / \mathrm{i}$ : normal, dan $>100 \mathrm{x} / \mathrm{i}$ : takikardia. Interpretasi hasil untuk respirasi rate <16 x/i: bradipnea, 1624 x/i: normal, dan $>24$ x/i: takipnea. ${ }^{14}$

\section{HASIL}

Berdasarkan karakteristik responden menunjukkan bahwa $(47,4 \%)$ responden dengan kelompok umur 36-45 tahun. Berdasarkan jenis kelamin menunjukkan bahwa $(50,9 \%)$ berjenis kelamin perempuan. Berdasarkan tingkat pendidikan menunjukkan bahwa $(38,6 \%)$ responden yang berpendidikan SMA. Berdasarkan lama terapi hemodialisa menunjukkan bahwa $(45,6 \%)$ responden yang sudah menjalani hemodialisa selama 1-3 tahun lebih banyak dibandingkan dengan yang lain. Berdasarkan jenis pembiayaan menunjukkan bahwa (100\%) dengan asuransi kesehatan. Berdasarkan penyakit penyerta menunjukkan bahwa $(49,1 \%)$ responden dengan hipertensi.

Tabel 1. Tingkat Kecemasan dengan Me an Arterial Pre s sure Sebelum Hemodialisis

\begin{tabular}{lccccc}
\hline \multicolumn{1}{c}{ Tingkat Kecemasan } & \multicolumn{2}{c}{ Mean Arterial Pressure } & & & \\
& $\begin{array}{c}\text { Pearson Correlation } \\
\text { Mean Arteriat } \\
\text { Pressure }\end{array}$ & $\begin{array}{c}\text { Tingkat } \\
\text { Kecemasan }\end{array}$ & Sig & RSquare & F \\
\hline $\begin{array}{l}\text { Mean Arteriat Pressure } \\
\text { Tingkat Kecemasan }\end{array}$ & $\begin{array}{l}1 \\
0.301\end{array}$ & $\begin{array}{c}0.301 \\
1\end{array}$ & 0.023 & 5.474 & 0.091 \\
\hline
\end{tabular}

Pada tabel uji signifikan, diperoleh nilai Pearson correlation sebesar 0,301 yang menunjukkan $\mathrm{r}(0,301) \neq 0$ berarti ada hubungan antara tingkat kecemasan dengan mean arterial pressure dan nilai signifikan sebesar 0,023 yang berarti nilai signifikannya kurang 
dari kriteria signifikan $(0,05)$ menunjukkan adanya hubungan antara tingkat kecemasan dengan mean arterial pressure.

Dari hasil analisa diatas diperoleh nilai $\mathrm{R}$ Square 0,091 berarti variabel tingkat kecemasan (X) memiliki pengaruh distribusi $9.1 \%$ terhadap variabel mean arterial pressure (Y). Hasil perhitungan regresi linier sederhana diatas memperlihatkan nilai dari $F_{\text {hitung }}>$ dari $F_{\text {tabel, }}$ dimana nilai $\mathrm{F}$ hitungnya 5.474 dan $\mathrm{F}$ tabelnya 4,02.

Tabel 2. Tingkat Kecemasan dengan Mean Arterial Pressure Setelah Hemodialisis

\begin{tabular}{lccccc}
\hline \multicolumn{1}{c}{ Tingkat Kecemasan } & \multicolumn{2}{c}{ Mean Arterial Pressure } & & & \\
& $\begin{array}{c}\text { Pearson Correlation } \\
\text { Mean Arteriat } \\
\text { Pressure }\end{array}$ & $\begin{array}{c}\text { Tingkat } \\
\text { Kecemasan }\end{array}$ & Sig & RSquare & F \\
\hline $\begin{array}{l}\text { Mean Arteriat Pressure } \\
\text { Tingkat Kecemasan }\end{array}$ & $\begin{array}{c}1 \\
0.295\end{array}$ & $\begin{array}{c}0.295 \\
1\end{array}$ & 0.026 & 0.087 & 5.239 \\
\hline
\end{tabular}

Pada tabel uji signifikan, diperoleh nilai Pearson correlation sebesar 0,295 yang menunjukkan $r(0,295) \neq 0$ berarti ada hubungan antara tingkat kecemasan dengan mean arterial pressure dan nilai signifikan sebesar 0,026 yang berarti nilai signifikannya kurang dari kriteria signifikan $(0,05)$ menunjukkan adanya hubungan antara tingkat kecemasan dengan mean arterial pressure.

Dari hasil analisa diatas diperoleh nilai $\mathrm{R}$ Square 0,087 berarti variabel tingkat kecemasan (X) memiliki pengaruh distribusi $8.7 \%$ terhadap variabel mean arterial pressure (Y). Hasil perhitungan regresi linier sederhana diatas memperlihatkan nilai dari

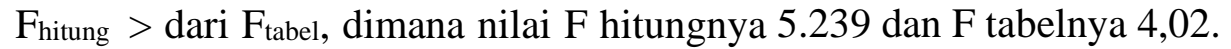

Tabel 3. Tingkat Kecemasan dengan Nadi Sebelum Hemodialisis

\begin{tabular}{lccccc}
\hline \multicolumn{1}{c}{ Tingkat Kecemasan } & \multicolumn{2}{c}{ Mean Arterial Pressure } \\
& Pearson Correlation & Tingkat \\
& Kecemasan & Sig & RSquare & F \\
\hline Nadi & 1 & 0.037 & 0.785 & 0.001 & 0.075 \\
Tingkat Kecemasan & 0.037 & 1 & & \\
\hline
\end{tabular}

Pada tabel uji signifikan, diperoleh nilai Pearson correlation sebesar 0,037 yang menunjukkan $\mathrm{r}(0,037) \neq 0$ berarti ada hubungan antara tingkat kecemasan dengan nadi dan nilai signifikan sebesar 0,785 yang berarti nilai signifikannya lebih dari kriteria signifikan $(0,05)$ menunjukkan tidak ada hubungan antara tingkat kecemasan dengan nadi.

Dari hasil analisa diatas diperoleh nilai $\mathrm{R}$ Square 0,001 berarti variabel tingkat kecemasan (X) memiliki pengaruh distribusi $0,1 \%$ terhadap variabel nadi (Y). Hasil perhitungan regresi linier sederhana diatas memperlihatkan nilai dari $\mathrm{F}_{\text {hitung }}<$ dari $\mathrm{F}_{\text {tabel }}$, dimana nilai $\mathrm{F}$ hitungnya 0,075 dan $\mathrm{F}$ tabelnya 4,02. 
Tabel 4. Tingkat Kecemasan dengan Nadi Setelah Hemodialisis Mean Arterial Pressure

\begin{tabular}{lcccccc}
\multicolumn{1}{c}{ Tingkat Kecemasan } & \multicolumn{2}{c}{$\begin{array}{c}\text { Pearson Correlation } \\
\text { Nadi }\end{array}$} & $\begin{array}{c}\text { Tingkat } \\
\text { Kecemasan }\end{array}$ & Sig & RSquare & F \\
\hline $\begin{array}{l}\text { Nadi } \\
\text { Tingkat Kecemasan }\end{array}$ & $\begin{array}{c}1 \\
0.003\end{array}$ & $\begin{array}{c}0.003 \\
1\end{array}$ & 0.984 & 0.000 & 0.000 \\
\hline
\end{tabular}

Pada tabel uji signifikan, diperoleh nilai Pearson correlation sebesar 0,003 yang menunjukkan $r(0,003) \neq 0$ berarti ada hubungan antara tingkat kecemasan dengan nadi dan nilai signifikan sebesar 0,984 yang berarti nilai signifikannya lebih dari kriteria signifikan $(0,05)$ menunjukkan tidak ada hubungan antara tingkat kecemasan dengan nadi.

Dari hasil analisa diatas diperoleh nilai $\mathrm{R}$ Square 0,000 berarti variabel tingkat kecemasan (X) memiliki pengaruh distribusi $0 \%$ terhadap variabel nadi (Y). Hasil perhitungan regresi linier sederhana diatas memperlihatkan nilai dari $\mathrm{F}_{\text {hitung }}<$ dari $\mathrm{F}_{\text {tabel }}$, dimana nilai $\mathrm{F}$ hitungnya 0,000 dan $\mathrm{F}$ tabelnya 4,02.

Tabel 5. Tingkat Kecemasan dengan Respirasi Rate Sebelum Hemodialisis

\begin{tabular}{|c|c|c|c|c|c|}
\hline \multirow[b]{2}{*}{ Tingkat Kecemasan } & \multicolumn{2}{|c|}{ Mean Arterial Pressure } & \multirow[b]{2}{*}{ Sig } & \multirow[b]{2}{*}{ RSquare } & \multirow[b]{2}{*}{$\mathrm{F}$} \\
\hline & Respirasi Rate & $\begin{array}{l}\text { Tingkat } \\
\text { Kecemasan }\end{array}$ & & & \\
\hline Respirasi Rate & 1 & 0.223 & 0096 & 0050 & 2874 \\
\hline Tingkat Kecemasan & 0.223 & 1 & 0.090 & 0.050 & $2.8 / 4$ \\
\hline
\end{tabular}

Pada tabel uji signifikan, diperoleh nilai Pearson correlation sebesar 0,223 yang menunjukkan $\mathrm{r}(0,223) \neq 0$ berarti ada hubungan antara tingkat kecemasan dengan respirasi rate dan nilai signifikan sebesar 0,096 yang berarti nilai signifikannya lebih dari kriteria signifikan $(0,05)$ menunjukkan tidak ada hubungan antara tingkat kecemasan dengan respirasi rate.

Dari hasil analisa diatas diperoleh nilai $\mathrm{R}$ Square 0,050 berarti variabel tingkat kecemasan (X) memiliki pengaruh distribusi 5\% terhadap variabel respirasi ratei (Y). Hasil perhitungan regresi linier sederhana diatas memperlihatkan nilai dari $F_{\text {hitung }}<$ dari $\mathrm{F}_{\text {tabel, }}$ dimana nilai $\mathrm{F}$ hitungnya 2,874 dan $\mathrm{F}$ tabelnya 4,02.

Tabel 6. Tingkat Kecemasan dengan Respirasi Rate Setelah Hemodialisis

\begin{tabular}{lccccc}
\hline \multicolumn{1}{c}{ Mean Arterial Pressure } \\
Tingkat Kecemasan & $\begin{array}{c}\text { Pearson Correlation } \\
\text { Respirasi Rate }\end{array}$ & $\begin{array}{c}\text { Tingkat } \\
\text { Kecemasan }\end{array}$ & Sig & RSquare & F \\
\hline Respirasi Rate & 1 & 0.085 & 0.528 & 0.007 & 0.403 \\
Tingkat Kecemasan & 0.085 & 1 & & \\
\hline
\end{tabular}

Pada tabel uji signifikan, diperoleh nilai Pearson correlation sebesar 0,085 yang menunjukkan $\mathrm{r}(0,085) \neq 0$ berarti ada hubungan antara tingkat kecemasan dengan respirasi rate dan nilai signifikan sebesar 0,528 yang berarti nilai signifikannya lebih dari kriteria 
signifikan $(0,05)$ menunjukkan tidak ada hubungan antara tingkat kecemasan dengan respirasi rate.

Dari hasil analisa diatas diperoleh nilai $\mathrm{R}$ Square 0,007 berarti variabel tingkat kecemasan (X) memiliki pengaruh distribusi $0,7 \%$ terhadap variabel respirasi ratei (Y). Hasil perhitungan regresi linier sederhana diatas memperlihatkan nilai dari $F_{\text {hitung }}<$ dari

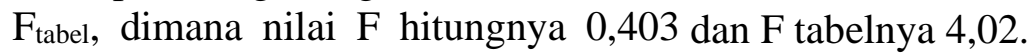

\section{PEMBAHASAN}

Karakteristik responden berdasarkan umur didapatkan bahwa paling paling banyak adalah umur 36-45 tahun sebanyak 47,4\%. Hal tersebut didukung oleh hasil penelitian dilakukan oleh Widiyati (2016) yang menunjukkan bahwa dari 30 responden 7 orang diantaranya $(23,3 \%)$ didapatkan paling banyak berumur 36-45 tahun. Gangguan kecemasan dimulai pada awal masa dewasa, antara usia 15 dan 25 tahun, tetapi angka terus meningkat setelah usia 35 tahun. Pada usia dewasa seseorang sudah memiliki kematangan fisik maupun mental dan pengalaman yang lebih dalam memecahkan masalah sehingga mampu menekan kecemasan yang dirasakan.

Berdasarkan jenis kelamin menunjukkan bahwa sebanyak 50,9\% berjenis kelamin perempuan. Jenis kelamin berhubungan terhadap respon penyakit, kecemasan, serta penggunaan koping dalam menghadapi masalah kesehatan khususnya pada pasien yang menjalani terapi hemodialisa. Hal tersebut didukung oleh hasil penelitian dilakukan oleh Suryadi (2012) yang menunjukkan bahwa dari 183 responden 97 diantaranya (53\%) didapatkan paling banyak berjenis kelamin perempuan.

Berdasarkan tingkat pendidikan menunjukkan bahwa yang paling banyak berpendidikan SMA yaitu sebanyak 38,6\%. Hal tersebut didukung oleh hasil penelitian dilakukan oleh Widiyati (2016) yang menunjukkan bahwa dari 30 responden 14 diantaranya $(46,7 \%)$ didapatkan paling banyak berpendidikan SMA. Hasil penelitian ini juga sesuai dengan Lestari (2017) yang menunjukkan bahwa dari 59 responden 30 diantaranya $(50,8 \%)$ berpendidikan SMA. Menurut teori Notoadmodjo dimana tingkat pendidikan yang rendah dapat mempengaruhi kecemasan yang tinggi pada pasien gagal ginjal kronik yang menjalani hemodialisis, hal ini disebabkan oleh pengetahuan dan daya serap akan terjadi pada dirinya. Pada pasien yang mempunyai pendidikan lebih tinggi akan mempunyai pengetahuan yang lebih luas, mempunyai rasa percaya diri yang tinggi, berpengalaman, mudah mengerti tentang apa yang dianjurkan petugas kesehatan, akan dapat mengurangi kecemasan sehingga dapat membantu pasien tersebut dalam mengambil keputusan.

Berdasarkan lama terapi hemodialisa menunjukkan bahwa sebanyak 45,6\% responden yang sudah menjalani hemodialisa selama 1-3 tahun lebih banyak dibandingkan dengan yang lain. Semakin lama menjalani hemodialisis maka dengan sendirinya responden semakin terbiasa menggunakan semua alat dan proses yang dilakukan saat hemodialisa, sementara responden yang pertama menjalani hemodialisis merasa bahwa ini merupakan suatu masalah yang sedang mengancam dirinya dan merasa hal yang dilakukan ini sangat menyiksa dirinya. Semakin lama pasien menjalani hemodialisis adaptasi pasien semakin baik karena pasien telah mendapat pendidikan kesehatan atau informasi yang terkait dengan penyakit gagal ginjal kronik dan pengobatannya. 
Berdasarkan jenis pembiayaan menunjukkan bahwa sebanyak 57 (100\%) dengan asuransi kesehatan. Berdasarkan penyakit penyerta menunjukkan bahwa yang paling banyak yaitu hipertensi sebanyak $28(49,1 \%)$ dan hipertensi + diabetes melitus sebanyak 13 (22,8\%). Berdasarkan Indonesia Society of Nephrology (inaSN) tahun 2000, diabetes dan hipertensi merupakan penyebab kedua dan ketiga gagal ginjal kronik di Indonesia setelah glomerulonefritis. Dari data tersebut dapat terlihat bahwa penyebab utama gagal ginjal kronik di Indonesia yaitu hipertensi dan diabetes melitus. Hal tersebut didukung oleh hasil penelitian dilakukan oleh Suryadi (2012) yang menunjukkan bahwa dari 183 responden 126 diantaranya $(68,9 \%)$ menderita hipertensi dan $61(33,3 \%)$ menderita diabetes melitus.

Hasil penelitian kecemasan berdasarkan kuesioner Zung Self Rating Anxiety Scale (ZSAS) menunjukkan bahwa responden gagal ginjal kronik yang menjalanai hemodialisa mengalami kecemasan ringan sebanyak 28 responden (49.1\%), namun juga tidak berbeda jauh dengan kecemasan sedang, kemudian diikuti dengan tidak ada kecemasan dan tidak ada yang mengalami kecemasan berat. Kecemasan ringan berhubungan dengan ketegangan dalam kehidupan sehari-hari dan menyebabkan seseorang menjadi waspada dan meningkatkan lahan persepsinya. Manifestasi yang muncul pada tingkat ini adalah kelelahan, iritabel, lapang persepsi meningkat, kesadaran tinggi, mampu untuk belajar, motivasi meningkat dan tingkah laku sesuai situasi dan dari hasil penelitian ini tampak bahwa yang paling muncul yaitu responden selalu merasa lemah dan mudah lelah sebanyak 52 responden (91.2\%). Kecemasan yang dialami oleh seseorang dapat ditimbulkan dari adanya sebuah ancaman yang dapat menimbulkan rasa ketakutan dan akhirnya merasa cemas atau khawatir. Hal tersebut didukung oleh hasil penelitian dilakukan oleh Ratnawati (2011), yang menunjukkan bahwa dari 15 responden 6 orang diantaranya (40\%) memiliki kecemasan ringan. ${ }^{15}$ Hasil penelitian ini juga sesuai dengan Tanvir (2013) yang menunjukkan sebagian besar pasien gagal ginjal kronik yang menjalani hemodialisis mengalami kecemasan ringan.

Berdasarkan hasil penelitian menunjukkan bahwa mean arterial pressure sebelum hemodialisis pada 39 responden $(68.4 \%)$ mengalami hipertensi begitu juga dengan mean arterial pressure pada 40 responden $(70.2 \%)$ setelah dilakukan hemodialisis sama-sama mengalami hipertensi. Hal ini dipengaruhi oleh beberapa faktor yaitu tahanan perifer, autonomic control dan cardiac output. 16

Mean Arterial Pressure adalah jumlah rata- rata dari seluruh tekanan yang dihitung dari millidetik sampai millidetik berikutnya selama periode tertentu. Nilai ini tidak sama dengan tekanan sistolik dan diastolic. Akan tetapi tekanan rata-rata tersebut lebih mendekati tekanan diastolik dari pada tekanan sistolik. Oleh karena itu mean arterial pressure diturunkan oleh sekitar $60 \%$ dari tekanan diastolik, dan $40 \%$ dari tekanan sistolik. Bahkan pada usia lanjut mean arterial pressure mendekati tekanan diastolik. Dari hasil penelitian yang dilakukan, mean arterial pressure sebelum dan setelah hemodialisis mengalami hipertensi. Hal tersebut didukung oleh hasil penelitian dilakukan oleh Haribudiman (2016) yang menunjukkan bahwa dari 47 responden, perubahan tekan an darah sebelum dan selama hemodialisis pada pasien menunjukkan bahwa rat a-rata tekanan darah sistolik dan diastolik sebelum hemodialisis lebih tinggi dari pada tekanan darah sistolik dan diastolik pada saat hemodialisis.

Berdasarkan hasil penelitian menunjukkan bahwa nadi responden sebelum hemodialisis pada 52 responden $(91.2 \%)$ sebagian besar normal begitu juga dengan nadi pada 50 responden $(87.7 \%)$ setelah dilakukan hemodialisis sama-sama normal. Jadi, nadi 
responden sebelum dan setelah hemodialisis yaitu normal. Nadi merupakan refleksi perifer dari kerja jantung dan penjalaran gelombang dari proksimal (pangkal aorta) ke distal. Gelombang nadi tidak bersamaan dengan aliran darah tetapi menjalar lebih cepat. Dari hasil penelitian yang dilakukan, nadi sebelum dan setelah hemodialisa cenderung normal. Hal tersebut didukung oleh penelitian yang dilakukan oleh Fajriati (2013) tentang Gambaran Hemodinamik Pasien Penyakit Ginjal Kronik Saat Menjalani Hemodialisa Berdasarkan Karakteristik Pasien Di RSUD Kota Semarang dari 54 responden didapatkan hasil rata-rata nadi cenderung normal dari jam I HD sampai post-HD. ${ }^{17}$

Berdasarkan hasil penelitian menunjukkan bahwa respirasi rate responden sebelum hemodialisis pada 53 responden (93\%) sebagian normal begitu juga dengan respirasi rate pada 55 responden $(96.5 \%)$ setelah dilakukan hemodialisis sama-sama normal. Dari hasil penelitian yang dilakukan, respirasi rate sebelum dan setelah hemodialisa cenderung normal. Pengaturan pernafasan terdiri dari pengaturan kimia dan saraf. Pengaturan kimia yaitu pusat pernafasan didalam sumsum sangat peka pada reaksi, kadar alkali darah harus dipertahankan. Karbondioksida adalah produk asam dari metabolism dan bahan kimia. Asam ini merangsang pusat pernafasan untuk mengirim keluar impuls saraf yang bekerja atas otot pernafasan. Peningkatan kadar $\mathrm{CO} 2$ dalam darah arteri dan cairan serebrospinalis merangsang peningkatan frekuensi dan kedalaman respirasi. Sedangkan pengaturan saraf yaitu pusat pernafasan adalah suatu pusat otomotik didalam medulla oblongata yang mengeluarkan impuls eferen ke otot pernafasan. Hal tersebut didukung oleh penelitian yang dilakukan oleh Maharsi (2017) tentang Perubahan Hemodinamik Pada Pasien yang dilakukan Terapi Hemodialisa Di Ruang Hemodialisa RSUD Dr. MOEWARDI didapatkan hasil rata-rata respirasi rate sebelum dan setelah hemodialisa cenderung normal.

Hasil analisis hubungan tingkat kecemasan dengan mean arterial pressure sebelum hemodialisis menggunakan uji Pearson correlation didapatkan nilai signifikan 0.023 yang berarti nilai signifikannya kurang dari kriteria signifikan $(0,05)$ menunjukkan adanya hubungan antara tingkat kecemasan dengan mean arterial pressure sebelum hemodialisis. Hasil perhitungan regresi linier sederhana diatas memperlihatkan nilai dari $F_{\text {hitung }}>$ dari $F_{\text {tabel, }}$, dimana nilai $F$ hitungnya 5.474 dan $F$ tabelnya 4,02 yang menunjukkan $\mathrm{H}_{0}$ ditolak berarti adanya "hubungan antara tingkat kecemasan dengan mean arterial pressure pasien gagal ginjal kronik yang sedang menjalani hemodialisa di ruang hemodialisa RSUD Raden Mattaher Jambi Tahun 2018".

Hasil analisis hubungan tingkat kecemasan dengan mean arterial pressure setelah hemodialisis menggunakan uji Pearson correlation didapatkan nilai signifikan 0,026 yang berarti nilai signifikannya kurang dari kriteria signifikan $(0,05)$ menunjukkan adanya hubungan antara tingkat kecemasan dengan mean arterial pressure setelah hemodialisis. Hasil perhitungan regresi linier sederhana diatas memperlihatkan nilai dari $\mathrm{F}_{\text {hitung }}>$ dari $\mathrm{F}_{\text {tabel }}$, dimana nilai $\mathrm{F}$ hitungnya 5.239 dan $\mathrm{F}$ tabelnya 4,02 yang menunjukkan $\mathrm{H}_{0}$ ditolak berarti adanya "hubungan antara tingkat kecemasan dengan mean arterial pressure pasien gagal ginjal kronik yang sedang menjalani hemodialisa di ruang hemodialisa RSUD Raden Mattaher Jambi Tahun 2018”. Hal ini dimungkinkan karena pasien gagal ginjal kronik yang menjalani terapi hemodialisa dihadapkan berbagai masalah finansial, kesulitan dalam mempertahankan pekerjaan, depresi dan ketakutan akan kematian yang akan menyebabkan kecemasan. ${ }^{5}$ Perubahan mean arterial pressure seseorang dapat dipengaruhi oleh berbagai faktor salah satunya adalah kecemasan. 
Hasil analisis hubungan tingkat kecemasan dengan nadi sebelum hemodialisis menggunakan uji pearson correlation didapatkan nilai signifikan sebesar 0,785 yang berarti nilai signifikannya lebih dari kriteria signifikan $(0,05)$ menunjukkan tidak ada hubungan antara tingkat kecemasan dengan nadi. Hasil perhitungan regresi linier sederhana diatas memperlihatkan nilai dari $F_{\text {hitung }}<$ dari $F_{\text {tabel }}$, dimana nilai Fhitungnya 0,075 dan $\mathrm{F}$ tabelnya 4,02 yang menunjukkan $\mathrm{H0}$ diterima berarti tidak ada "hubungan antara tingkat kecemasan dengan nadi pasien gagal ginjal kronik yang sedang menjalani hemodialisa di ruang hemodialisa RSUD Raden Mattaher Jambi Tahun 2018”.

Hasil analisis hubungan tingkat kecemasan dengan nadi setelah hemodialisis menggunakan uji pearson correlation didapatkan nilai signifikan sebesar 0,984 yang berarti nilai signifikannya lebih dari kriteria signifikan $(0,05)$ menunjukkan tidak ada hubungan antara tingkat kecemasan dengan nadi. Hasil perhitungan regresi linier sederhana diatas memperlihatkan nilai dari $\mathrm{F}_{\text {hitung }}<$ dari $\mathrm{F}_{\text {tabel}}$, dimana nilai $\mathrm{F}$ hitungnya 0,000 dan $\mathrm{F}$ tabelnya 4,02 yang menunjukkan $\mathrm{H}_{0}$ diterima berarti tidak ada "hubungan antara tingkat kecemasan dengan nadi pasien gagal ginjal kronik yang sedang menjalani hemodialisa di ruang hemodialisa RSUD Raden Mattaher Jambi Tahun 2018”.

Kecemasan menimbulkan respon fisiologis dan psikologis yang saling berhubungan. Dampak dari psikologis akan mempengaruhi fisiologis salah satunya adalah nadi. Apabila pasien mengalami kecemasan maka akan berdampak pada peningka tan denyut jantung. Nadi merupakan refleksi perifer dari kerja jantung dan penjalaran gelombang dari proksimal (pangkal aorta) ke distal. Gelombang nadi tidak bersamaan dengan aliran darah tetapi menjalar lebih cepat. Kecepatan penjalaran nadi menurun pada beberapa penyakit jantung, darah atau pembuluh darah, tapi meningkat pada yang lain. Kakunya dinding arteri akibat proses penuaan dan aterosklerosis mempercepat gelombang nadi. Intensitas nadi berhubungan dengan karakteristik pembuluh darah dan tekanan nadi.14 Refleks baroreseptor merupakan reflek paling utama dalam menentukan pengaturan pada denyut jantung dan tekanan darah yang dirangsang oleh distensi dan peregangan dinding aorta. Saat tekanan darah arteri meningkat dan arteri menegang, reseptor ini dengan cepat mengirim sinyal ke pusat vasomotor sehingga terjadi penghambatan pusat vasomotor yang mengakibatkan vasodilatasi pada arteriol dan vena serta menurunkan tekanan darah. Penurunan tekanan darah tersebut kemudian menurunkan tahanan perifer dan dilatasi vena yang menyebabkan darah menumpuk pada vena sehingga mengurangi aliran balik yang menyebabkan terjadinya penurunan curah jantung. Impuls aferen dari baroreseptor juga mencapai pusat jantung yang akan merangsang aktivitas parasimpatis dan menghambat pusat simpatis sehingga menyebabkan penurunan denyut dan daya kontraksi jantung. 19 Faktor yang mempengaruhi frekuensi nadi adalah penyakit, emosi, usia, latihan fisik, suhu yang meningkat ataupun menurun, jenis kelamin, posisi, olahraga, dan obat-obatan. ${ }^{20}$

Hal tersebut didukung oleh penelitian yang dilakukan oleh Fajriati (2013) tentang Gambaran Hemodinamik Pasien Penyakit Ginjal Kronik Saat Menjalani Hemodialisa Berdasarkan Karakteristik Pasien Di RSUD Kota Semarang dari 54 responden didapatkan hasil rata-rata nadi cenderung normal dari jam I HD sampai post-HD. ${ }^{18}$

Hasil analisis hubungan tingkat kecemasan dengan respirasi rate sebelum hemodialisis menggunakan uji pearson correlation didapatkan nilai signifikan sebesar 0,096 yang berarti nilai signifikannya lebih dari kriteria signifikan $(0,05)$ menunjukkan tidak ada hubungan antara tingkat kecemasan dengan respirasi rate. Hasil perhitungan regresi 


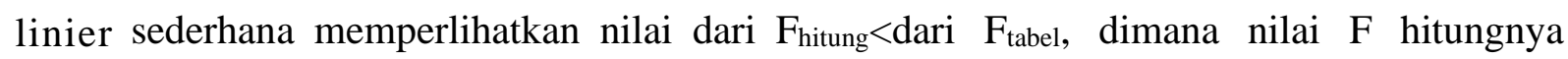
2,874 dan $\mathrm{F}$ tabelnya 4,02 yang menunjukkan $\mathrm{H}_{0}$ diterima berarti tidak ada "hubungan antara tingkat kecemasan dengan respirasi rate pasien gagal ginjal kronik yang sedang menjalani hemodialisa di ruang hemodialisa RSUD Raden Mattaher Jambi Tahun 2018".

Hasil analisis hubungan tingkat kecemasan dengan respirasi rate setelah hemodialisis menggunakan uji pearson correlation didapatkan nilai signifikan sebesar 0,528 yang berarti nilai signifikannya lebih dari kriteria signifikan $(0,05)$ menunjukkan tidak ada hubungan antara tingkat kecemasan dengan respirasi rate. Hasil perhitungan regresi

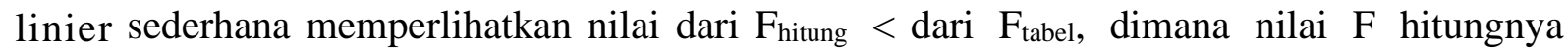
0,403 dan $\mathrm{F}$ tabelnya 4,02 yang menunjukkan $\mathrm{H}_{0}$ diterima berarti tidak ada hubungan antara tingkat kecemasan dengan respirasi rate pasien gagal ginjal kronik yang sedang menjalani hemodialisa di ruang hemodialisa RSUD Raden Mattaher Jambi Tahun 2018. Pada pasien gagal ginjal kronik umumnya akan terjadi kompensasi pengeluaran asam dengan cara hiperventilasi untuk mengeluarkan $\mathrm{CO}_{2}$. Akan tetapi pada saat menjalankan hemodialisa kemungkinan kecepatan pernapasan pasien akan kembali normal karena hasil metabolism yang bersifat asam akan di ekskresikan pada saat proses hemodialisa. Hal inilah memungkinkan dapat menyebabkan tidak terdapatnya hubungan antara tingkat kecemasan dengan respirasi rate.

\section{KESIMPULAN}

Berdasarkan hasil penelitian "Hubungan Tingkat Kecemasan Dengan Kondisi Hemodinamik Pasien Gagal Ginjal Kronik Yang Sedang Menjalani Hemodialisa Di Ruang Hemodialisa RSUD Raden Mattaher Jambi Tahun 2018" didapatkan bahwa pada penelitian ini yang mengalami kecemasan ringan lebih banyak dibandingkan dengan tingkat kecemasan lainnya yaitu sebanyak 28 (49.1\%), kecemasan sedang sebanyak 20 (35.1\%), tidak ada kecemasan sebanyak $9(15.8 \%)$ dan kecemasan berat $0(0 \%)$. Berdasarkan Me an arterial pressure sebelum hemodialisis pada 39 responden $(68.4 \%)$ mengalami hipertensi begitu juga dengan mean arterial pressure pada 40 responden $(70.2 \%)$ setelah dilakukan hemodialisis sama-sama mengalami hipertensi. Kemudian nadi dan respirasi rate sebelum dan setelah hemodialisis cenderung normal. Ada hubungan antara tingkat kecemasan dengan Mean Arterial Pressure (MAP) pasien gagal ginjal kronik yang sedang menjalani hemodialisa di ruang Hemodialisa RSUD Raden Mattaher Jambi Tahun 2018. Sedangkan nadi, dan respirasi rate tidak terdapat hubungan.

\section{SARAN}

Hasil penelitian ini diharapkan perawat di Ruang Hemodialisa RSUD Raden Mattaher Jambi lebih memperhatikan masalah kecemasan pasien dan dampak kecemasan terhadap tindakan hemodialisa. Kemudian perlu dilakukan pemantauan mengenai perubahan hemodinamik sebelum, pada saat dan setelah hemodialisa untuk mengantisipasi memburuknya keadaan.

\section{DAFTAR PUSTAKA}

National Kidney Foundation. About Chronic Kidney Disease; 2013 
RISKESDAS. Badan Penelitian dan Pengembangan Kesehatan. Jakarta: Kementerian Kesehatan RI; 2013.

Infodatin. Situasi Penyakit Ginjal Kro- nis. Pusat Data dan Informasi Kementrian Kesehatan RI: 2017.

RSUD Raden Mattaher Jambi. Rekapitulasi Pasien Yang Menjalani Hemodialisa Tahun 2014-2016. Jambi: 2017.

Brunner \& Suddarth. Buku Ajar Keper- awatan Medikal-Bedah. Edisi 8. Jakarta: EGC; 2013.

Rahmi W. Gambaran tentang tingkat kecemasan pasien yang pertama kali menjalani Hemodialisa di Ruang Hemodialisa RSUD Kraton. Penelitian Keperawatan Medikal Bedah; 2008.

Rika D. Hubungan antara Intensitas Shalat dengan Kecemasan Menghadapi Hemodialisa pada Pasien Gagal Ginjal. Malang: Fakultas Psikologi Universitas Muhammadiyah; 2006.

Ross, A.F \& Kearney. Dyalisis Disequilibrium Syndrome. American Journal of Nursing. $100,53-54 ; 2000$.

Hudak \& Gallo. Keperawatan Kritis Pendekatan Holistik. Edisi IV, Volume 2. Jakarta: EGC; 1996.

Saryono. Kumpulan Instrumen Penelit- ian Kesehatan. Yogyakarta: Nuha Medi- ka; 2011.

Landry, D.W \& Oliver, J.A. Blood Pressure Instability During Hemodialysis; 2006.

Nursalam. Konsep Penerapan Metode Penelitian Ilmu Keperawatan. Jakarta: Salemba Medika; 2013.

Weinstock, Doris. Rujukan Cepat di Ruang ICU/ICCU. Edisi pertama. Jakar- ta: EGC; 2010 .

Willms, Janice L. Diagnosis Fisik : Evaluasi Diagnosis dan Fungsi di Bangsal. Jakarta: EGC; 2003

Ratnawati. Tingkat Kecemasan Pasien Dengan Tindakan Hemodialisa Di BLUD RSU Dr. MM Dunda Kabupaten Gorontalo. Journal Health and Sport.2011.

Schumacher, L., \& Chernecky, C. Saun- ders Nursing Survival Guide Critical Care and Emergency Nursing 2nd ed.United states of america: Saunders El- sevier; 2010.

Fajriati, A.D. Gambaran Hemodi-namik Pasien Penyakit Ginjal Kronik Saat Menjalani Hemodialisa Berdasarkan Karakteristik Pasien Di RSUD Kota Se- marang. Skripsi. Universitas Muham- madiyah Semarang; 2013.

Wahyuningsih, Z \& Nugroho SHP, Mu'ah. Hubungan Cemas Dengan Pen- ingkatan Tekanan Darah Pada Pasien Pre Operasi di Ruangan Bourgenvil RSUD DR. SOEGIRI Lamongan. 2011. 
Ganong, W. F. Buku Fisiologi Kedok- teran Ed 22. Jakarta: EGC; 2008

Hegner, B. R., \& Caldwell, E. Asisten Keperawatan : suatu pendekatan proses keperawatan. Ed 6. Jakarta: EGC; 2003. 